\title{
Emerging therapies for pancreatic ductal carcinoma
}

\author{
Robert Falcone ${ }^{1}$, Paul J. Davis ${ }^{1,2}$, Steven C. Stain ${ }^{3}$, Shaker A. Mousa*1 \\ ${ }^{1}$ The Pharmaceutical Research Institute, 1 Discovery Drive, Albany College of Pharmacy and Health Sciences, Rensselaer, NY, \\ USA \\ ${ }^{2}$ Department of Medicine, Albany Medical College, Albany, NY, USA \\ ${ }^{3}$ Department of Surgery, Albany Medical College, Albany, NY, USA
}

Received: November 2, 2015

DOI: $10.5430 /$ jst.v6n1p65
Accepted: December 16, 2015 Online Published: January 25, 2016

URL: http://dx.doi.org/10.5430/jst.v6n1p65

\begin{abstract}
Pancreatic ductal adenocarcinoma (PDAC) is a solid tumor mass that grows and metastasizes rapidly. There are no definitive methods for early detection and most patients are diagnosed at a late stage. Those diagnosed at an early stage are eligible for tumor resection. However, many of these patients are soon burdened with tumor recurrence. The tumor grows back aggressively and with resistance to the original chemotherapy. Gemcitabine has been the treatment of choice, but provides only minimal survival prolongation. Researchers are trying to improve the current standard of care by finding different methods to improve treatment efficacy and reduce side effects. This review emphasizes recent data on targeting the tumor using antifibrotic, nanotargeted, and dendritic cell therapies. Antifibrotic therapy aims to reduce tumor fibrosis, which prevents adequate chemotherapy penetration. Nanotargeted therapy offers precise targeting of cancer cells and chemotherapy delivery. Dendritic cell vaccines stimulate the body's immune system to target PDAC cells. These three treatment methods or a combination of them might improve the lifespan and quality of life for PDAC patients.
\end{abstract}

Key Words: Pancreatic cancer, Nanotechnology, Nanotargeted, Antifibrotic, Immunotherapy, Dendritic cells

\section{INTRODUCTION}

Pancreatic cancer is a unique cancer that is extremely difficult to treat and just as difficult to diagnose at a treatable state. Pancreatic cancer is almost always diagnosed as pancreatic ductal adenocarcinoma (PDAC) and makes up roughly 90 percent of all pancreatic cancer cases. ${ }^{[1]}$ Despite monumental advances in oncology therapy in the past few decades, PDAC still has a 5-year survival rate of only 5 percent. For the year 2015 in the US, the estimated number of new cases of pancreatic cancer was 48,960 and number of deaths due to pancreatic cancer was $40,560 .^{[2]}$ These numbers have been increasing in western countries. The disease is equally prevalent in men and women. ${ }^{[3]}$ A minority of patients are diagnosed at a resectable point. However, mainly due to adverse events and tumor recurrence, their 5-year survival is still less than 20 percent. ${ }^{[4]}$

\subsection{Established risk factors and high risk of recurrence}

Little is known about pancreatic cancer risk factors and their actual significance toward developing pancreatic cancer. However certain studies have demonstrated a potential link between incidences of pancreatic cancer and smoking cigarettes,${ }^{[5]}$ consuming fats from animal meat, ${ }^{[6]}$ hypercholesterolemia, and alcohol consumption. ${ }^{[7]}$ Evidence is still

\footnotetext{
* Correspondence: Shaker A. Mousa; Email: shaker.mousa@acphs.edu; Address: The Pharmaceutical Research Institute, 1 Discovery Drive, Albany College of Pharmacy and Health Sciences, Rensselaer, NY, USA.
}

Published by Sciedu Press 
lacking, but the suggestions made in these articles provide a potential base for new studies.

In terms of potential causative oncogenic mutations, K-Ras mutations are associated with an increased risk of pancreatic lesions, a precursor to pancreatic cancer. For example, intraductal papillary mucinous neoplasms (IPMN) are being recognized as an important precursor. ${ }^{[8]} \mathrm{K}$-Ras activation from inflammation in mouse models has been shown to cause pancreatic lesions. ${ }^{[9]}$ A separate study showed that mice with inducible K-Ras mutations initiated carcinogenesis by inhibiting the repair of the pancreas. ${ }^{[10]}$ This same study showed that inactivation of K-Ras led to tumor regression. Codon 12 is the most frequently affected K-Ras substituent. One study that tested for codon 12 mutations using human pancreatic cancer cells showed that codon 12 mutations occurred in 72.2 percent of samples tested. ${ }^{[11]} \mathrm{K}$-Ras activation can lead to subsequent somatic mutations of tumor suppressor genes p16, p53, and DPC4. ${ }^{[12]}$

Roughly 15 percent of patients with PDAC are lucky enough to be eligible for potentially curative resection. ${ }^{[4]}$ However, most patients will develop cancer recurrence and die from metastatic disease. In a retrospective analysis performed by Van den Broeck et al., 110 patients who received PDAC resection were followed. ${ }^{[13]}$ The overall survival (OS) was a median of 18.7 months. Every patient in this study had a recurrence. Most patients $(75 \%)$ had recurrence in the peritoneal cavity, although only $17 \%$ of the recurrences were in the pancreatic bed, suggesting that metastases occurred frequently despite an adequate local resection.

Many attempts have been made to improve imaging techniques and thereby diagnose patients at an earlier phase. Little improvement has been seen in this field and MRI and CT imaging remain the best available options. Contrast dye is often needed for these imaging procedures but has potential side effects of allergy hypersensitivity and nephrotoxicity. A safer and more effective contrast could reduce adverse effects and improve outcomes in patients during initial diagnosis, as well as monitor for recurrence. While not covered in this review, McCarroll et al. extensively evaluates how nanoformulations can improve contrast agents and in turn outcomes. ${ }^{[14]}$

\subsection{Pathophysiology of the tumor}

PDAC is a solid tumor that is unique for its intricate stroma that makes up most of its mass. The stroma is composed of myofibroblasts, endothelial cells, pericytes, and immune cells along with its extracellular matrix (ECM). ${ }^{[15]}$ It is a highly fibrotic tumor, and this fibrotic environment allows the tumor to grow rapidly and be relatively impermeable to systemic chemotherapy. The unique nature of the tumor presents clinicians with difficult obstacles to overcome. With early signs often being back pain or gastrointestinal discomfort, early diagnosis is more difficult than many other cancers. In turn, the majority of patients are diagnosed at a late stage.

The dense tumor mass components are activated by pancreatic stellate cells (PSCs). PSCs secrete a vast amount of profibrotic factors, which work to increase tumor fibrosis. ${ }^{[16]}$ PSCs have been proven to increase vascular endothelial growth factor (VEGF), a factor that increases tumor angiogenesis. However, fibrosis occurs at a much faster rate than angiogenesis. This creates a hypoxic environment in the tumor. This lack of blood supply is another hurdle to overcome when trying to deliver chemotherapy to the tumor. Hypoxia was also found to significantly increase ECM proteins such as periostin, type-I and III collagen, and fibronectin. ${ }^{[16,17]}$ This process will accelerate fibrosis even more.

\subsection{Current approved agents and their expected out- comes}

Systemic chemotherapeutic agents for PDAC have been studied extensively. Effectively delivering chemotherapy to this dense, hypoxic tumor has proved difficult due to poor tumor penetration. Gemcitabine, a nucleoside inhibitor, is currently the gold standard treatment, but it increases overall survival by less than two months in patients with unresectable PDAC. The addition of erlotinib, an epidermal growth factor inhibitor, has been shown to increase OS to a median of 6.24 months vs. 5.91 months $(P=.038) .{ }^{[18]}$ FOLFIRINOX, a regimen consisting of oxaliplatin, irinotecan, fluorouracil, and leucovorin has shown the best results in terms of OS (11.1 months vs. 6.8 months gemcitabine group, $P<.001$ ) in metastatic pancreatic cancer. However, due to a higher incidence of adverse events, FOLFIRINOX is only recommended for patients with good performance status. ${ }^{[19]}$ Analysis of results from the PRODIGE 4/ACCORD 11 randomized trial showed a significant improvement in quality of life when compared with gemcitabine in patients with metastatic pancreatic cancer. This same study showed a significant increase in time to definitive deterioration. ${ }^{[20]}$

Nab-paclitaxel plus gemcitabine was studied in a phase III trial named MPACT to determine if the combination would improve outcomes for metastatic pancreatic cancer when compared to the gold standard gemcitabine. ${ }^{[21]}$ The MPACT trial was a randomized, open label study of 861 patients at 151 sites across the world. The nab-paclitaxel arm resulted in a significantly longer median OS (8.7 vs. 6.6 months, $P$ $<.001$ ) when compared to gemcitabine alone. In an update report on the longer term OS, 4 percent of patients in the 
nab-paclitaxel arm were identified as long term survivors (> 3 years), compared to no patients in the gemcitabine control group. The patients in the nab-paclitaxel group did experience an increased prevalence of any-grade neutropenia, leukopenia, fatigue, peripheral neuropathy, and diarrhea. No significant increase was seen in any-grade anemia or thrombocytopenia. ${ }^{[22]}$

A 2013 phase III study by Ueno et al. studied a newer oral fluoropyrimidine derivative called $S-1 .{ }^{[23]}$ This study showed S-1 to be non-inferior to gemcitabine. The study also tried to establish superiority of gemcitabine and S-1 to gemcitabine alone but failed to do so with statistical significance. S-1 is not yet approved in the United States, but if approved it would provide an oral alternative to gemcitabine.

Nab-paclitaxel was the first nanotechnology-modified systemic chemotherapy studied in PDAC; ${ }^{[24]}$ results are discussed in more detail later in this review. A summary of chemotherapeutic agents and their respective results are listed in Table 1.

Table 1. A summary of phase III trials comparing the current standard of care, gemcitabine, to other regimens

\begin{tabular}{|c|c|c|c|c|}
\hline \multirow{2}{*}{$\begin{array}{l}\text { Phase III studied regimen } \\
\text { vs. gemcitabine (gem) alone }\end{array}$} & \multicolumn{4}{|c|}{ Median overall survival (months) } \\
\hline & Experimental & Control & $\boldsymbol{P}$ & Reference \\
\hline gem + erlotinib & 6.24 & 5.91 & .038 & [93] \\
\hline FOLFIRINOX & 11.1 & 6.8 & $<.001$ & [19] \\
\hline gem + nab-paclitaxel & 8.7 & 6.6 & $<.001$ & [22] \\
\hline gem + capecitabine & 7.1 & 6.2 & .08 & [94] \\
\hline gem + cetuximab & 6.3 & 5.9 & .23 & [95] \\
\hline $\begin{array}{l}\text { gem + bevacizumab + erlotinib } \\
\text { vs. gem + erlotinib }\end{array}$ & 7.1 & 6.0 & .2087 & [96] \\
\hline gem + cisplatin & 8.3 & 7.2 & .38 & [97] \\
\hline gem + S-1 & 10.1 & 8.8 & .15 & [23] \\
\hline${ }^{1} \mathrm{~S}-1$ & 9.7 & 8.8 & $<.001$ non-inferiority & [23] \\
\hline
\end{tabular}

Note. ${ }^{1} \mathrm{~S}-1$ vs. gemcitabine was only tested on a non-inferiority basis.

\subsection{Synergy and targeted therapy}

Synergy involves the use of two chemotherapeutic agents, where the auxiliary agent's purpose is to improve the response to the primary agent, and remains an interesting proposition in PDAC treatment. With outcomes being so poor in PDAC, all avenues are being investigated. An example of synergy is a study by Wong et al. that cotargeted EGFR and PI3K using erlotinib and BYL (PI3K alpha inhibitor) in pancreatic cancer cell lineages resistant to EGFR. ${ }^{[25]}$ The authors hypothesized that by inhibiting $\mathrm{PI} 3 \mathrm{~K}$, an enzyme responsible for cell proliferation, growth, and survival, resistance to erlotinib could be reduced. The authors concluded that patients with resistance to EGFR had higher levels of PI3K-akt. Multiple targets were tested for sensitivity, but the combination of erlotinib and BYL was capable of overcoming EGFR resistance.

VEGF is another intriguing target. The monoclonal antibody bevacizumab is a VEGF inhibitor. In addition to promoting tumor growth, VEGF is a potent pro-angiogenic growth factor. In a phase II trial, Martin et al. tested bevacizumab, gemcitabine, and fluorouracil (5-FU) infusion in patients with advanced stage pancreatic cancer. ${ }^{[26]}$ The results were a median OS of 7.4 months. Unfortunately, there was no gemcitabine control group in this study to show clinical significance. However, the regimen was well tolerated by the study population. The authors concluded that bevacizumab showed an improvement likely due to the synergy associated with using adjuvant 5-FU therapy.

Immunotherapeutic is another field gaining momentum, especially the subclass of dendritic cell vaccines. The modification of human blood to target specific factors in the tumor has been successful in other types of cancer. An optimal treatment hypothesis for PDAC would be a host-mediated immune reaction to the tumor, resulting in tumor cell lysis and T-cell memory. Dendritic cell therapies are covered later in this review.

The emergence of nanotechnology offers many options to improve current regimens and target aspects of the tumor that are impossible to treat with conventional chemotherapy. A main purpose of nanotechnology in medicine is to optimize drug delivery. As a result, increased drug efficacy and decreased systemic side effects are possible and seen often. Biomarkers that are based on the tumor's mechanism of growth could become viable targets in nanotherapy and they continue to be explored. Unfortunately, it is difficult to translate promising results in the lab setting to the clinical 
setting. IGF-1R is a hormone that is thought to regulate cell proliferation, survival, angiogenesis, and invasion. ${ }^{[27]}$ Seemingly a viable target for nanotherapy, establishing a clinical response has proved difficult. An example of this was seen in a 2014 study by Philip et al. ${ }^{[28]}$ This study compared a dual blockade of erlotinib on EGFR and cixutumumab on IGF-1R $v s$. erlotinib in 116 patients. Both arms were in combination with gemcitabine. The treatment group was not superior to the control arm with any significance.

This review article will focus on emerging antifibrotic, nanotargeted, and dendritic cell therapies.

\section{THE POTENTIAL FOR ANTIFIBROTICS}

The unique stroma in PDAC has proved challenging for researchers. A potential target lies within PSCs, which once activated, will produce factors composing the ECM. PSCs transform into a myofibroblastic state once activated and secrete excessive amounts of collagen I, III, fibronectin, and matrix degrading enzymes such as matrix metalloproteinase. ${ }^{[17]}$ Proangiogenic molecules such as periostin and VEGF are also secreted. ${ }^{[16,17]}$ A focus on nanotargeting of stellate cells has amplified in recent years.

Various techniques trying to soften the stroma offer promise. Angiotensin receptor II blockers (ARBs) have recently been used to reverse the fibrotic nature of the stroma. A study by Masamune et al. showed that in mice olmesartan dosed at $10 \mathrm{mg} / \mathrm{kg}$ daily reduced collagen deposition and alphasmooth muscle actin, which is a precursor for the activation of PSCs. The authors concluded that olmesartan inhibited growth of the pancreatic tumor size by inhibiting the activity of PSCs57. ${ }^{[29]}$ While a novel idea, it seems that administering a very high dose of olmesartan daily would likely cause severe hypotension in patients who are normotensive. A study by Phillips et al. done in mice showed an increase in tumor uptake of chemotherapeutics and an improved response to chemotherapy using a novel sulfated non-anticoagulant, low molecular weight heparin (S-NACH). S-NACH plus paclitaxel showed increased tumor growth suppression and survival when compared to paclitaxel alone. ${ }^{[30]}$ In the same study similar results were seen when comparing S-NACH and doxorubicin.

Table 2. Possible antifibrotic therapies and their corresponding mechanism or action

\begin{tabular}{|c|c|c|}
\hline Drug name & Mechanism of action & Reference \\
\hline Olmesartan & $\begin{array}{l}\text { Reduce collagen deposition and reduce activation of alpha-smooth muscle } \\
\text { actin }\end{array}$ & {$[29]$} \\
\hline $\begin{array}{l}\text { Non-anticoagulant low molecular } \\
\text { weight heparin (S-NACH) }\end{array}$ & $\begin{array}{l}\text { Mechanism unknown, but has shown improved chemo uptake into the } \\
\text { tumor }\end{array}$ & {$[30]$} \\
\hline Pirfenidone & $\begin{array}{l}\text { Reduces fibroblast production, alpha-smooth muscle actin, pro-collagen } \\
\text { mRNA, and proteins; not yet studied in pancreatic cancer }\end{array}$ & {$[32]$} \\
\hline PEGPH20 & $\begin{array}{l}\text { Depletes hyaluronan, an extracellular matrix tumor component; results in } \\
\text { normalized interstitial fluid pressure and improved drug delivery }\end{array}$ & {$[33,34]$} \\
\hline
\end{tabular}

Another novel idea for reducing PDAC fibrosis could involve experimental treatment with a new antifibrotic agent called pirfenidone. While the agent has only been FDAapproved to treat idiopathic pulmonary fibrosis, the mechanism of action should translate successfully in the treatment of PDAC. ${ }^{[31]}$ The drug works by reducing fibroblast proliferation, TGF-beta induced alpha-smooth muscle actin, pro-collagen mRNA, and protein. ${ }^{[32]}$ The use of pirfenidone could theoretically reduce the fibrosis associated with PDAC as well as improve chemotherapy penetration.

Studies have also been performed trying to target hyaluronan, another ECM component that is thought to be the cause of increased interstitial fluid pressure (IFP) and a reduced vascular function inside the fibrotic mass. The end result of increased hyaluronan expression is thought to be a decreased delivery of chemotherapy throughout the tumor. PEGPH20 is a pegylated formulation of human recombinant $\mathrm{PH} 20$ hyaluronidase, an enzyme that breaks down hyaluronan in the body. ${ }^{[33]}$ A study by Provenzano et al. assessed the possibilities for using enzymes to target the stroma with hopes to increase efficacy of chemotherapy. ${ }^{[34]}$ The authors used PEGPH20 to deplete hyaluronan in mice PDAC cells. Despite depletion of hyaluronan in the pancreas and other organs, no decline in function was seen in mice models. The authors note an immediate decrease in IFP, with values approaching the normal range after only 24 hours. A study by Jacobetz et al. investigated a similar topic and concluded that PEGPH20 significantly reduced the amount of hyaluronan, promoting the expansion of blood vessels. The authors found that when combined with gemcitabine, PEGPH20 inhibited tumor growth and prolonged survival vs. gemcitabine alone in mice models. ${ }^{[33]}$ A summary of antifibrotic therapies and 
their respective mechanisms of action are listed in Table 2.

\section{NANOTECHNOLOGY AND NANOTARGET- ING}

\subsection{Current methods in nanotechnology for targeting and delivery}

Nanotechnology is defined by the National Nanotechnology Initiative as "science, engineering, and technology conducted at the nanoscale, which is about 1 to 100 nanometers". [35] The target ligand, the target location, drug characteristics and pharmacokinetics, and even the type of tumor can all factor into which nanotechnology platform will be used for drug delivery. This improvement in targeting and controlled release of the drug normally results in better efficacy and improved tolerability. Potential nanotechnology platforms for drug delivery include liposomes, dendrimers, gold nanoshells, polymer-based nanoparticles and micelles, and metallic and magnetic nanoparticles. ${ }^{[36,37]}$ Liposomes are lipid-based vesicles that can carry hydrophilic molecules in their aqueous compartment or they can carry hydrophobic molecules in their lipid bilayer. ${ }^{[38]}$ Dendrimers have repeating branches stemming from a central core. The branches can present both drug and a targeting agent. The hydrophobic core can encapsulate nonpolar molecules in a series of interactions. ${ }^{[39]}$ Gold nanoparticles are capable of delivering proteins, DNA or RNA; drugs can also easily be attached. ${ }^{[39]}$ Polymer-based nanoparticles and micelles can both encapsulate or covalently bind drug. Encapsulation usually is reserved for hydrophobic drugs. Hydrophilic drugs are usually covalently bound. ${ }^{[37]}$ Magnetic nanoparticles can be modified to target a tumor site just by changing the biocompatible coating. The reactive outer coating can be loaded with therapeutic agents. ${ }^{[40,41]}$

Many nanoparticles can be formulated in a two-stage delivery system. This allows for good penetration into the tumor and rapid release once inside the tumor. Two-stage nanoparticles utilize the enhanced permeability and retention effect (EPR). A study by Danhier et al. used paclitaxel-loaded micelles to enhance transvascular permeability and retention of nanomedicine in tumors in mice. The study hypothesized that changing the micro-environment of a solid tumor by enhancing blood flow would improve EPR. Paclitaxel was used due to its broad spectrum of activity, which most importantly with regard to EPR can inhibit angiogenesis. ${ }^{\text {[2] }}$ The administration of paclitaxel-loaded micelles normalized tumor vasculature and decreased IFP. ${ }^{[42]}$ These findings are important because an increased EPR would result in an improved response with future doses of nanotherapy.

Multi-stage delivery is also an option when trying to reduce binding to non-cancerous cells or penetrate only a portion of the tumor as is sometimes seen with two-stage delivery nanoparticles. The release of loaded drug is not as rapid once entering the tumor. Stylianopoulos et al. discussed whether a multi-stage delivery system with slower drug release would be more effective at targeting the entire tumor; also the optimal size and pharmacokinetics were assessed. ${ }^{[43]}$ In solid tumors even nanoparticles 100 nanometers in size may be too big. While nanotechnology offers an opportunity to improve chemotherapy, the authors discovered that in solid tumors 100 nanometer nanoparticles were less compartmentalized inside the tumor than normal chemotherapy. This improved penetration in normal chemotherapy was due to the drugs' small size. The authors concluded that the ideal parameters for a nanoparticle would be 20 nanometers in size for the primary portion. This size allows for excellent penetration into the tumor, and with vessel wall pore size normally not exceeding $12 \mathrm{~nm}$, the risk for extravasation to healthy tissue is low. Mildly timed release kinetics were also suggested to find a balance between effective concentrations and penetrating the tumor in its entirety. ${ }^{[4]}$ This is a novel idea-to this point methods have been mainly focused on altering the fibrotic structure to help internalization of chemotherapy.

\subsection{Using nanotechnology to improve current systemic chemotherapy treatments}

There is an abundance of techniques being examined to improve PDAC patient outcomes. Trying to improve a systemic regimen with nab-paclitaxel is one method used. Nabpaclitaxel is a 130 nanometer particle that consists of albumin and paclitaxel bound noncovalently for enhanced accumulation of paclitaxel into the tumor via albumin-mediated enhanced permeation and retention. This formulation is marketed as Abraxane ${ }^{\circledR}$ and has significantly reduced infusion sight reactions when compared with paclitaxel. The nanoformulation can be reconstituted with saline, whereas paclitaxel used to be reconstituted with Cremophor ${ }^{\circledR}$ EL, which is a castor oil-based solvent and invokes a high risk for hypersensitivity reactions. Fortunately, with nab-paclitaxel there is no need to pre-medicate. Nab-paclitaxel has shown promise when combined with gemcitabine, providing a 2 month increase in median OS (8.5 vs. 6.7 months with gemcitabine monotherapy). Nab-paclitaxel in combination with gemcitabine also showed a significant reduction in neutropenia and fatigue when compared to the FOLFIRINOX regimen, but an increase in peripheral neuropathy was seen. ${ }^{[24]}$

Because gemcitabine is the current gold standard in PDAC treatment, the use of nanotechnology to improve gemcitabine therapy is no surprise. Patra et al. showed that gemcitabineloaded gold nanoparticles targeted with cetuximab showed improved in vitro efficacy $v s$. gemcitabine in PANC-1 cancer 
cells. $^{[44]}$ Another study by Li et al. showed that gemcitabineloaded albumin nanospheres were effective inhibitors of PANC-1 cells both in vivo and in vitro. ${ }^{[45]}$ A more recent 2015 in vitro study by Jaidev et al. assessed gemcitabine loaded in biodegradable poly (lactide-co-glycolide) (PLGA) nanospheres for treatment of pancreatic cancer. ${ }^{[46]}$ PLGA is an FDA-approved polymer used to control drug delivery to the target site. ${ }^{[47]}$ Jaidev et al. observed a significant reduction in IC50 of 45 percent for MiaPACa-2 and ASPC-1 pancreatic cancer cells in vitro. The authors postulated that a potential reduction in adverse events along with increased efficacy warrants in vivo studies of PLGA nanospheres loaded with gemcitabine. ${ }^{[46]}$

Advancements in nanotechnology have expanded the scope of nanotargeting. An emerging target in oncology is SPARC (secreted protein acidic and rich in cysteine). It is a calcium binding glycoprotein that is secreted into the $\mathrm{ECM}^{[48,49]}$ and has been shown to have an effect on many cancer growth processes from proliferation to angiogenesis. Increased levels of SPARC have been linked with a poorer prognosis in the majority of cancers. However, data involving the effects of SPARC on PDAC are controversial. The majority of PDAC cell lineages show no potential for SPARC expression. ${ }^{[48,50]}$ However, two of the more prominent PDAC cell lineages, PANC-1 and MiaPaCa-2, both appear to exhibit moderate to high levels of SPARC expression. ${ }^{[51]}$ Despite being linked with a poorer prognosis in most types of cancer, SPARC's high affinity for albumin has resulted in an intriguing correlation; ${ }^{[52]}$ treatment of PDAC with nab-paclitaxel provides for better penetration due to SPARC's affinity for albumin. In addition, nab-paclitaxel appears to deplete the stroma, allowing for an increased response rate to systemic drugs such as gemcitabine. More in-depth information about SPARC in pancreatic cancer is available in a review by Vaz et al. ${ }^{[48]}$

\subsection{Taking a multi-modal approach with nanotechnol- ogy}

Combination therapy is often attempted to improve patient outcomes. While some attempts have been discussed above, this section will focus on the use of nanotechnology in combination with therapies attacking the stroma and its components. A study by Meng et al. tested a two-wave approach using nanotherapy to increase the efficacy of gemcitabine. ${ }^{[53]}$ Initially the gemcitabine was encapsulated in a pegylated drug-carrying liposome to improve delivery. However, the stroma interfered with the delivery of drug, so a pre-infusion nanocarrier was created to reduce the pericyte coverage of the vasculature by interfering with the pericyte recruiting TGF-beta pathway. The authors were able to prove that in a xenograft model the tumor could be shrunk and the stromal resistance to the gemcitabine-loaded nanocarrier could be overcome. ${ }^{[53]}$

Hypoxia-inducible factor 1 alpha (HIF1alpha) is a transcription factor vital to PDAC tumor cell survival. ${ }^{[54]}$ The hypoxic conditions of the dense stroma have been described previously. HIF1alpha is a subunit of the HIF heterodimer, which is activated in hypoxic conditions and is recognized as a vital transcription factor for tumor progression. ${ }^{[55]}$ In a cohort of 81 PDAC patients, those with medium to high expression of HIF1alpha proteins had a significantly worse OS compared to those patients with negative or low HIF1alpha protein expression. ${ }^{[56]}$ A 2015 study by Zhao et al. tested whether or not HIF1alpha siRNA and gemcitabine lipid-polymer nanoparticles would show an improvement over current gemcitabine therapy. In vivo testing of human xenograft transplants into mice confirmed that gemcitabine was capable of inhibiting tumor growth. After HIF1alpha knockdown via HIF1alpha siRNA, the cytotoxicity of gemcitabine was significantly enhanced in tumor cells. ${ }^{[57]}$

A study performed by de la Fuente et al. examined whether a nano-enabled interfering RNA could act as a chemotherapy booster. ${ }^{[58]}$ Interfering RNA or RNAi has the ability to switch off certain genes at a post-transcriptional level ${ }^{[59]}$ and both p53 and p73 are thought to provide synergy with chemotherapeutic agents. ${ }^{[60]}$ The de la Fuente et al. evaluated RNAi acting on p73 to promote sensitization to chemotherapy. They concluded that dendrimers were successful in transfecting pancreatic cancer cells for the RNAi agents used in the study. When a combination of p73 RNAi and gemcitabine was administered in animals, the treatment group saw 17 days without any tumor growth. Tumor growth over a 4-week period was also significantly reduced compared to those untreated. The treatment was also deemed very well tolerated and no difference in weight loss was seen. The authors also noted the therapy was highly efficacious, and the downregulation of p73 suppressors (or upregulation of p73) led to tumor-specific sensitization with gemcitabine. Thus, further human-based studies are warranted.

Integrin $\alpha \mathbf{v} \beta 3$ is a structural protein of the plasma membrane whose extracellular domain contains receptors for large molecule (extracellular matrix protein) ${ }^{[61]}$ and small molecule (thyroid hormone) ${ }^{[62]}$ ligands. The integrin is primarily expressed by tumor cells and dividing endothelial cells. A thyroid hormone analogue, tetraiodothyroacetic acid (tetrac), acts at $\alpha \mathrm{v} \beta 3$ to generate intracellular signals that disorder expression of genes critical to cancer cell survival pathways, to angiogenesis, to cell division and repair of double-strand DNA breaks. ${ }^{[62-64]}$ Inside the tumor cell, unmodified tetrac lacks these properties. ${ }^{[62]}$ Covalently 
bound via a linker to a $120-150 \mathrm{~nm}$ nanoparticle, tetrac as Nano-diamino-tetrac (Nanotetrac) acts exclusively at the integrin $^{[65]}$ as an anticancer, anti-angiogenic agent. It has been shown to be effective against human pancreatic cancer cell xenografts ${ }^{[66]}$ via induction of apoptosis and antiangiogenesis by multiple mechanisms. This nanotechnologic design strategy has resulted in increased anticancer potency of Nano-diamino-tetrac vs. tetrac at the integrin by up to 10 -fold ${ }^{[62]}$ and to broaden the agent's anticancer transcriptional activity. For example, Nano-diamino-tetrac (but not unmodified tetrac) decreases expression of the EGFR gene and proto-oncogenic, pro-angiogenic miR-21 (SA Mousa, T Sudha: unpublished observations) and increases expression of pro-apoptotic BCL2L14. ${ }^{[63,64]}$ Non-dividing, nonmalignant cells express small quantities of $\alpha \mathrm{v} \beta 3$, so that the preclinical studies of this nanoparticulate drug have revealed little toxicity. Clinical trials of the agent in pancreatic carcinoma are proposed for 2016.

PSCs as targets for therapy are being approached in a vari- ety of ways. Recent studies have hypothesized how PSCs become activated. Retinol is stored in the cytoplasm of inactivated PSCs, and a lack of retinol intake has been linked with PSCs' activation, resulting in tumor growth. ${ }^{[17,41]}$ Some studies have reported that administration of retinoic acid can deactivate PSCs. ${ }^{[41,67,68]}$ A study by Michael et al. analyzed the effect of retinoic acid in combination with gemcitabine in patients with non-resectable pancreatic carcinoma but was unable to show any statistically significant value. It is known that the fibrotic stroma of PDAC leads to difficulties in drug penetration. Lack of penetration of retinoic acid could have led to its reduced efficacy. ${ }^{[69]}$ This issue was addressed by Yalçin et al. who examined whether using magnetic nanoparticles loaded with gemcitabine and all-trans retinoic acid (ATRA) in a PBS buffer would improve outcomes compared to previous studies. They found that magnetic nanoparticles loaded with $10 \mu \mathrm{M}$ of gemcitabine and ATRA in buffer was an efficient way to deliver drug to the tested human pancreatic cancer cell lines. ${ }^{[41]}$

Table 3. Immunotherapeutic agents and strategies for management of pancreatic ductal adenocarcinoma

\begin{tabular}{|c|c|c|}
\hline \multicolumn{3}{|l|}{ Selected vaccines } \\
\hline Product & Description & Mechanism of action \\
\hline GV1001 & $\begin{array}{l}\text { 16-amino acid peptide sequence from human } \\
\text { telomerase (hTERT) }\end{array}$ & $\begin{array}{l}\text { Induction of anti-hTERT to reduce enzyme } \\
\text { contribution to cancer cell survival }{ }^{[98]}\end{array}$ \\
\hline Algenpantucel-L & $\begin{array}{l}\text { Whole cell vaccine derived from } 2 \text { human pancreatic } \\
\text { cancer cell lines modified to express } \\
\alpha(1-3) \text { galactoysyl ( } \alpha \mathrm{GAL}) \text { epitopes }\end{array}$ & $\begin{array}{l}\text { Induction of tumor cell-mediated acute rejection } \\
\text { via generation of } \alpha(1-3) \text { antibodies }\end{array}$ \\
\hline GVAX & $\begin{array}{l}\text { Whole cell vaccine derived from } 2 \text { irradiated } \\
\text { pancreatic cancer cell lines modified to express } \\
\text { granulocyte-macrophage colony-stimulating factor } \\
\text { (GM-CSF) }\end{array}$ & $\begin{array}{l}\text { Recruitment to tumors of antigen-presenting cells } \\
\text { of several types to survey tumor proteins }{ }^{[100]}\end{array}$ \\
\hline CRS-207 & $\begin{array}{l}\text { Live attenuated Listeria monocytogenes bacteria } \\
\text { modified to express mesothelin }\end{array}$ & $\begin{array}{l}\text { Delivery of antigen (mesothelin) to dendritic cells } \\
\text { to activate CD4+, CD } 8+T \text { lymphocytes }\end{array}$ \\
\hline \multicolumn{3}{|c|}{ Selected immune checkpoint inhibitors } \\
\hline Ipilimumab & $\begin{array}{l}\text { Anti-cytotoxic T lymphocyte-associated protein } 4 \\
\text { (CTL4 antibody) }\end{array}$ & $\begin{array}{l}\text { Inhibition of downregulation by CTL4 of T cell } \\
\text { responses to tumor cells }{ }^{[102]}\end{array}$ \\
\hline $\begin{array}{l}\text { Pembrolizumab, } \\
\text { nivolumab }\end{array}$ & $\begin{array}{l}\text { Monoclonal antibody (-ies) to PD-L1 expressed by } \\
\text { multiple cancers }\end{array}$ & $\begin{array}{l}\text { Inhibition of downregulation by PD-L1 of } \\
\text { immune response to tumor cells, e.g., immune } \\
\text { blockade of suppression by PD-L1 of T cell } \\
\text { activation and of promotion by PD-L1 of T cell } \\
\text { apoptosis }{ }^{[103,104]}\end{array}$ \\
\hline
\end{tabular}

\section{IMMUNOTHERAPY}

Exploitation of components of cancer patients' immune systems to identify and kill cancer cells is attractive conceptually because of the limited applicability of surgery and radiation therapy and limited effectiveness of standard chemotherapy, e.g., gemcitabine or FOLFIRINOX. Immune system anticancer components include cytotoxic CD8+ T

Published by Sciedu Press

cells, Tn helper-1 (Th-1) cells, mature dendritic cells, activated macrophages and killer T cells. ${ }^{[70]}$ But PDAC typically is fibrotic, hypovascular, and largely devoid of lymphocytes that may be recruited to the immunotherapeutic process. ${ }^{[71]}$ Despite these handicaps, a number of vaccinebased strategies-where "vaccine" applies to therapy and not to prevention, in contrast to usage in infectious diseases- 
and immune checkpoint inhibition or blockade approaches have been tested in the past 5 or more years (see Table 3 ). Where these have appeared to show promise, the success has been limited to minorities of tumor populations, and specific biomarkers are currently lacking to identify potentially responsive tumors. Finally, activation of the immune system in an effort to stimulate lymphocyte killing of cancer cells risks inactivation of immune system tolerance of normal, nonmalignant cells and can cause dysfunction of previously healthy organs, e.g., antibodies to programmed cell death ligand-1 (PD-L1) (see Table 3). A number of reviews of vaccine and immune checkpoint inhibitor immunotherapy strategies in pancreatic cancer have recently appeared. ${ }^{\text {[1-75] }}$ These reviews include combinatorial therapy with anticancer vaccine and immune checkpoint blockade-immune checkpoint blockade alone appears to be effective against a number of cancers and includes the required induction of a satisfactory adaptive immune response. PDAC may not exhibit a satisfactory adaptive immune response to checkpoint blockade, ${ }^{[72]}$ but the immune response to checkpoint blockage may be heightened with the addition of vaccine therapy.

High-grade immune system-dependent systemic toxicity may occur in a substantial minority of patients who receive immune checkpoint inhibitors. ${ }^{[75]}$ It would obviously be beneficial to limit the action of drugs that affect the immune checkpoint to tumor cells. An approach that may do so is Nanodiamino-tetrac, discussed in Section 3.3. It has been shown to decrease transcription of the gene for PD-L1. ${ }^{[76]}$ This non-immunologic strategy for decreasing tumor-relevant immune checkpoint inhibition at PD-L1 offers the prospect of reduced systemic toxicity.

\subsection{Introduction to dendritic cells}

The use of dendritic cells (DCs) has recently gathered momentum in the oncology world. DCs allow for a high level of specificity when targeting a cancer cell, as long as the target ligand is specific to that cell. DCs have been used in cancer immunotherapy as well as in cancer nanotherapy. In immunotherapy DCs are effective in producing natural killer and $\mathrm{T}$ cells to fight cancer. An added benefit to this approach is the production of humoral immunity. With the risk of recurrence so high in PDAC, humoral immunity would be a huge advancement in PDAC treatment. Dendritic cells are the most potent antigen-presenting cell, and they are vital in regulating immune responses to tumors by presenting tumor antigens to T cells. ${ }^{[77]}$ The use of DCs in oncology would be classified as biologic therapy, and should be differentiated from nanotherapeutic dendrimers. DCs have been used to target specific tumor-associated antigens on MHC class 1 molecules. DCs are manipulated with different MHC-1 peptides to induce antigen-specific immunity. ${ }^{[78,79]}$ Most DC-based vaccines are produced to target CD8+ cytotoxic T lymphocytes. CD8+ targeting vaccines have not yet been able to translate promising lab-based results to clinical trials. ${ }^{[80]}$ Finding the right target is proving to be difficult.

\subsection{Production of dendritic cells}

Methods for the production of DC vaccine appear to be similar between studies. DCs are derived from peripheral blood mononuclear cells (PBMCs) in healthy donors. PBMCs must be separated from the donor plasma via a centrifuge. Then the PBMC product is collected and washed in RPMI1640 medium to continue to isolate PBMCs. The PBMCs are then plated in RPMI1640 for 2 hours at $37^{\circ} \mathrm{C}$ with 5 percent $\mathrm{CO}_{2}$. After the initial cultivation, the PBMCs are again washed in RPMI1640 to remove non-adherent cells. After this point the vaccine production varied by research group. However, the adherent PBMCs were usually cultured in the presence of human recombinant granulocyte-macrophage colony-stimulating factors (hGM-CSF) and human recombinant interleukin-4 (hIL-4). After roughly 5 days of culture, an adherent-premature DC sample can be obtained. The DCs can then be pulsed with the target ligand and activated using TNF-alpha. ${ }^{[79,81-84]}$

\subsection{Uses in PDAC therapy and outcomes}

Evidence has shown that the Wilms' tumor gene 1 (WT1) is overexpressed in pancreatic cancer. ${ }^{[79,85]}$ In a study by Koido et al. it was hypothesized that disease stability could be achieved with the use of multiple WT1-specific MHC class I/II restricted epitopes. ${ }^{[79]}$ The study reports results from a phase I clinical trial done in patients with stage IV PDAC by administering gemcitabine in combination with DCs pulsed with MHC-I/II restricted WTI epitopes. The DC vaccines were well tolerated. The vaccines appeared to provide clinical benefit only to those patients who were delayed-type hypersensitivity (DTH) positive. ${ }^{[79]}$ DTH is an inflammatory reaction mainly occurring at the injection site of cancer vaccines that is mediated by CD4+ effector memory T-cells. ${ }^{[79,86]}$ A positive result was a suspected stimulation of long-term memory T-cells, which would be a great aid in preventing PDAC recurrence. ${ }^{[79]}$ The long-term results of this study were published by Takakura et al. ${ }^{[82]}$ Of the 7 patients who received DC/WT1-I/II and chemotherapy, 3 were identified as super-responders; patients were classified as super-responders if they had an OS of $>12$ months. All patients who were classified as DTH-positive were also identified as super-responders. When the paper was published one super-responder was still alive (> 760 days) and the other two super-responders survived 582 and 717 days after first treatment. ${ }^{[82]}$ Considering that all of the patients had stage 
IV PDAC upon inclusion and the median OS of gemcitabine is roughly 6 months, these results are extremely promising.

A single arm, non-randomized, open-label study done by Bapsy et al. tested the use of DC vaccine in various solid tumor cancers in advanced disease states. ${ }^{[81]}$ APCEDEN is a formulation of dendritic cells used in this study and is derived from $\mathrm{CD} 14+$ monocytes, which is further described in Romani et al. ${ }^{[87]}$ Bapsy et al. concluded that the APCEDEN therapy leads to no major toxicity and is safe. Patients who were classified as responders had a median OS of 397 days and a significant improvement in quality of life, justifying the need for advanced development and randomized control trials. $^{[81]}$

Another single arm study performed by Shindo et al. tested DCs transfected with MUC1-mRNA and cytotoxic lymphocytes in addition to gemcitabine in 42 patients with unresectable pancreatic cancer. ${ }^{[88]} \mathrm{MUC} 1$ is Mucin 1 , an antigen that is overexpressed in all cancer cell lineages of PDAC. ${ }^{[89]}$ This makes MUC1 an ideal target for DCs because it should have efficacy against the entire tumor. While no control arm was included in the Shindo et al., the median time of survival was 13.9 months, with no severe toxicities associated with the DC therapy. Equally as impressive, liver metastasis occurred in only 5 patients among the 35 who didn't experience metastasis prior to treatment, equating to 14 percent of patients. ${ }^{[88]}$ Liver metastasis is a common complication with PDAC that imposes detrimental outcomes. One study showed that liver metastasis occurred in 73 percent of patients. ${ }^{[90]}$

The use of DCs in immunotherapy was also studied by Yin et al. ${ }^{[83]} \quad$ They examined the antitumor effects of loading DCs with pancreatic cancer stem cells (CSCs) in vitro. The authors expanded on recent information that CD44+CD24+ESA+ pancreatic CSCs have been confirmed to possess an increased tumorigenic potential. ${ }^{[91]}$ The Yin et al. used human blood samples to isolate DCs and used TNF-alpha to activate them. When applied to PANC-1 CSCs the DC CSCs showed a significant killing effect. This study presented important findings and will likely fuel new in vivo studies. As researchers in the past have shown, CSCs are likely one of the causes for resistance to therapy and relapse. ${ }^{[92]}$

The theory of immunotherapy provides a unique opportunity to use a patient's immune system to fight and prevent relapse of cancer. Due to the complexity of the immune system, finding the right target might be an issue.

\section{Conclusion}

Recent data in the field of PDAC treatment has shown that there is great potential for improvement. Considering the low

Published by Sciedu Press percentage of PDAC patients who are alive after 5 years, a major breakthrough cannot come soon enough. Researchers are heavily invested in different techniques to improve outcomes, tolerability of treatments, and life expectancy. One of the topics of this review involved mechanisms for reducing tumor fibrosis and interstitial tumor pressure. This was done by targeting various aspects of the stroma like collagen, fibrin, and hyaluronan. We saw conclusive evidence in the studies presented that in both mice and human models antifibrotics could provide improved drug penetration. In addition, a new antifibrotic named pirfenidone has recently been released. We made the suggestion that based on pirfenidone's mechanism of action, it could have value for clinicians who are trying to reduce fibrosis in PDAC.

Nanotechnology offers a multitude of different options for PDAC researchers. A method covered here is the use of nanotechnology to improve current chemotherapeutic efficacy. This was seen in the nanoformulation of drugs like gemcitabine. The objective was to improve tumor destruction and reduce side effects. The studies assessed show that nanotechnology can improve the current standard of care. The technology behind nanotherapy is improving rapidly, and treatment advancements are likely to be more profound in this disease state as work continues.

This review also evaluated recent literature in DC immunotherapy. Studies included in this review showed the potential in using a patient's own immune system to battle the tumor. Promising results have been reported, with DTHpositive responders reacting extremely well in the Takakura study. ${ }^{[82]}$ DC vaccines will likely soon become the choice adjuvant to gemcitabine in patients with pancreatic cancer and more specifically PDAC. Due to the complex manufacturing process behind biologics, production and patenting of DCs may be high hurdles to overcome in the future. Largerscaled studies comparing the vaccine and gemcitabine to gemcitabine alone should be performed to allow clinicians to see the possibilities of DC immunotherapy.

A topic not reviewed here was cost-benefit analysis. With extensive data involving benefit in humans lacking, it would be impossible to include cost-benefit information at this time. As the technology becomes more advanced, the cost of treatment may increase. Biologics tend to be very expensive due to their difficult manufacturing protocols. Erlotinib, a tyrosine kinase inhibitor used as an adjunct to gemcitabine in the treatment of PDAC, was shown to provide a median OS of roughly 0.3 months longer than gemcitabine alone. As unfortunate as it may be, patients with such a poor prognosis will have difficult decisions to make regarding their therapy because of cost. 
In conclusion, much work is still needed in this field. It is evident that PDAC is proving to be more stubborn to available treatments than other types of cancer. Despite the slightly disappointing advancements relative to other fields in oncology, knowledge is growing quickly in this field and new treatment agents and techniques are emerging. Significant

\section{REFERENCES}

[1] Maron R, Schechter B, Mancini M, et al. Inhibition of pancreatic carcinoma by homo- and heterocombinations of antibodies against EGF-receptor and its kin HER2/ErbB-2. Proc Natl Acad Sci USA. 2013; 110(38): 15389-94. PMid:24003140. http://dx.doi.org /10.1073/pnas. 1313857110

[2] American Cancer Society. What are the key statistics about pancreatic cancer? [cited 2015 Sept 16]. Available from: http://www. cancer.org/cancer/pancreaticcancer/det ailedguide/pancreatic-cancer-key-statistics

[3] Siegel RL, Miller KD, Jemal A. Cancer statistics, 2015. CA Cancer J Clin. 2015; 65(1): 5-29. http://dx.doi.org/10.3322/caac . 21254

[4] Maitra A, Hruban RH. Pancreatic cancer. Annu Rev Pathol. 2008; 3: 157-88. PMid:18039136. http://dx.doi.org/10.1146/ann urev.pathmechdis.3.121806.154305

[5] Kuzmickiene I, Everatt R, Virviciute D, et al. Smoking and other risk factors for pancreatic cancer: a cohort study in men in Lithuania. Cancer Epidemiol. 2013; 37(2): 133-9. PMid:23107757. http: //dx.doi.org/10.1016/j.canep.2012.10.001

[6] Thiebaut AC, Jiao L, Silverman DT, et al. Dietary fatty acids and pancreatic cancer in the NIH-AARP diet and health study. J Natl Cancer Inst. 2009; 101(14): 1001-11. PMid:19561318. http: //dx.doi.org/10.1093/jnci/djp168

[7] La Torre G, Sferrazza A, Gualano MR, et al. Investigating the synergistic interaction of diabetes, tobacco smoking, alcohol consumption, and hypercholesterolemia on the risk of pancreatic cancer: a case-control study in Italy. Biomed Res Int. 2014; 2014: 481019. PMid:24877100. http://dx.doi.org/10.1155/2014/481019

[8] Tan MC, Basturk O, Brannon AR, et al. GNAS and KRAS Mutations Define Separate Progression Pathways in Intraductal Papillary Mucinous Neoplasm-Associated Carcinoma. J Am Coll Surg. 2015; 220(5): 845-54 e1. PMid: 25840541. http://dx.doi.org/10.10 $16 / \mathrm{j} \cdot$ jamcollsurg. 2014.11.029

[9] Daniluk J, Liu Y, Deng D, et al. An NF-kappaB pathway-mediated positive feedback loop amplifies Ras activity to pathological levels in mice. J Clin Invest. 2012; 122(4): 1519-28. PMid:22406536. http://dx.doi.org/10.1172/JCI59743

[10] Collins MA, Bednar F, Zhang Y, et al. Oncogenic Kras is required for both the initiation and maintenance of pancreatic cancer in mice. J Clin Invest. 2012; 122(2): 639-53. PMid:22232209. http://dx.doi.org/10.1172/JCI59227

[11] Wu J, Zhou Y, Zhang CY, et al. Co-amplification at lower denaturation-temperature PCR combined with unlabled-probe highresolution melting to detect KRAS codon 12 and 13 mutations in plasma-circulating DNA of pancreatic adenocarcinoma cases. Asian Pac J Cancer Prev. 2014; 15(24): 10647-52. PMid:25605154. http://dx.doi.org/10.7314/APJCP.2014.15.24.10647 advancements should be expected in the future.

\section{CONFlicts OF InTEREST Disclosure}

Paul J. Davis and Shaker A. Mousa are co-inventors of Nanodiamino-tetrac and stockholders in a company that holds issued and pending patents for Nano-diamino-tetrac. All other authors declare no conflicts of interest.
[12] Hilgers W, Kern SE. Molecular genetic basis of pancreatic adenocarcinoma. Genes Chromosomes Cancer. 1999; 26(1): 112. http://dx.doi.org/10.1002/(SICI) 1098-2264(199909 ) $26: 1<1:: A I D-G C C 1>3.0 . C 0 ; 2-X$

[13] Van den Broeck A, Sergeant G, Ectors N, et al. Patterns of recurrence after curative resection of pancreatic ductal adenocarcinoma. Eur J Surg Oncol. 2009; 35(6): 600-4. PMid:19131205. http://dx.doi.org/10.1016/j.ejso.2008.12.006

[14] McCarroll J, Teo J, Boyer C, et al. Potential applications of nanotechnology for the diagnosis and treatment of pancreatic cancer. Front Physiol. 2014; 5: 2. PMid:24478715. http://dx.doi.org/10.33 89/fphys. 2014.00002

[15] Ino Y, Yamazaki-Itoh R, Shimada K, et al. Immune cell infiltration as an indicator of the immune microenvironment of pancreatic cancer. Br J Cancer. 2013; 108(4): 914-23. PMid:23385730. http://dx.doi.org/10.1038/bjc.2013.32

[16] Erkan M, Reiser-Erkan C, Michalski CW, et al. Cancer-stellate cell interactions perpetuate the hypoxia-fibrosis cycle in pancreatic ductal adenocarcinoma. Neoplasia. 2009; 11(5): 497-508. PMid:19412434. http://dx.doi.org/10.1593/neo.81618

[17] Apte MV, Haber PS, Applegate TL, et al. Periacinar stellate shaped cells in rat pancreas: identification, isolation, and culture. Gut. 1998; 43(1): 128-33. PMid:9771417. http://dx.doi.org/10.1136/g ut. 43.1 .128

[18] Stathis A, Moore MJ. Advanced pancreatic carcinoma: current treatment and future challenges. Nat Rev Clin Oncol. 2010; 7(3): 163 72. PMid:20101258. http://dx.doi.org/10.1038/nrclinonc .2009 .236

[19] Conroy T, Desseigne F, Ychou M, et al. FOLFIRINOX versus gemcitabine for metastatic pancreatic cancer. N Engl J Med. 2011; 364(19): 1817-25. PMid:21561347. http://dx.doi.org/10.1056/NEJMo a1011923

[20] Gourgou-Bourgade S, Bascoul-Mollevi C, Desseigne F, et al. Impact of FOLFIRINOX compared with gemcitabine on quality of life in patients with metastatic pancreatic cancer: results from the PRODIGE 4/ACCORD 11 randomized trial. J Clin Oncol. 2013; 31(1): 23-9. PMid:23213101. http://dx.doi.org/10.1200/J C0. 2012.44.4869

[21] Von Hoff DD, Ervin T, Arena FP, et al. Increased survival in pancreatic cancer with nab-paclitaxel plus gemcitabine. N Engl J Med 2013; 369(18): 1691-703. PMid:24131140. http://dx.doi.org /10.1056/NEJMoa1304369

[22] Goldstein D, El-Maraghi RH, Hammel P, et al. nab-Paclitaxel plus gemcitabine for metastatic pancreatic cancer: long-term survival from a phase III trial. J Natl Cancer Inst. 2015; 107(2). http: //dx.doi.org/10.1093/jnci/dju413

[23] Ueno H, Ioka T, Ikeda M, et al. Randomized phase III study of gemcitabine plus S-1, S-1 alone, or gemcitabine alone in patients with locally advanced and metastatic pancreatic cancer in Japan and Taiwan: 
GEST study. J Clin Oncol. 2013; 31(13): 1640-8. PMid:23547081. http://dx.doi.org/10.1200/JC0.2012.43.3680

[24] Neesse A, Michl P, Tuveson DA, et al. nab-Paclitaxel: novel clinical and experimental evidence in pancreatic cancer. Z Gastroenterol. 2014; 52(4): 360-6. PMid:24687799. http://dx.doi.org/10.10 $55 / \mathrm{s}-0034-1366002$

[25] Wong MH, Xue A, Julovi SM, et al. Cotargeting of epidermal growth factor receptor and PI3K overcomes PI3K-Akt oncogenic dependence in pancreatic ductal adenocarcinoma. Clin Cancer Res. 2014; 20(15): 4047-58. PMid:24895459. http://dx. doi .org/10.1158 /1078-0432. CCR-13-3377

[26] Martin LK, Li X, Kleiber B, et al. VEGF remains an interesting target in advanced pancreas cancer (APCA): results of a multiinstitutional phase II study of bevacizumab, gemcitabine, and infusional 5-fluorouracil in patients with APCA. Ann Oncol. 2012; 23(11): 2812-20. PMid:22767582. http://dx. doi .org/10. 1093 /annonc/mds 134

[27] Ma J, Sawai H, Matsuo Y, et al. IGF-1 mediates PTEN suppression and enhances cell invasion and proliferation via activation of the IGF-1/PI3K/Akt signaling pathway in pancreatic cancer cells. J Surg Res. 2010; 160(1): 90-101. PMid:19560785. http: //dx.doi.org/10.1016/j.jss.2008.08.016

[28] Philip PA, Goldman B, Ramanathan RK, et al. Dual blockade of epidermal growth factor receptor and insulin-like growth factor receptor1 signaling in metastatic pancreatic cancer: phase $\mathrm{Ib}$ and randomized phase II trial of gemcitabine, erlotinib, and cixutumumab versus gemcitabine plus erlotinib (SWOG S0727). Cancer. 2014; 120(19): 29805. PMid:25041791. http://dx.doi.org/10.1002/cncr. 28744

[29] Masamune A, Hamada S, Kikuta K, et al. The angiotensin II type I receptor blocker olmesartan inhibits the growth of pancreatic cancer by targeting stellate cell activities in mice. Scand J Gastroenterol. 2013; 48(5): 602-9. PMid:23477656. http://dx.doi .org/10.31 $09 / 00365521.2013 .777776$

[30] Phillips PG, Yalcin M, Cui H, et al. Increased tumor uptake of chemotherapeutics and improved chemoresponse by novel nonanticoagulant low molecular weight heparin. Anticancer Res. 2011; 31(2): 411-9. PMid:21378319.

[31] King TE Jr., Bradford WZ, Castro-Bernardini S, et al. A phase 3 trial of pirfenidone in patients with idiopathic pulmonary fibrosis. N Engl J Med. 2014; 370(22): 2083-92. PMid:24836312. http://dx.doi.org/10.1056/NEJMoa1402582

[32] Conte E, Gili E, Fagone E, et al. Effect of pirfenidone on proliferation, TGF-beta-induced myofibroblast differentiation and fibrogenic activity of primary human lung fibroblasts. Eur J Pharm Sci. 2014; 58: 13-9. PMid:24613900. http://dx.doi.org/10.1016/j.ejp s.2014.02.014

[33] Jacobetz MA, Chan DS, Neesse A, et al. Hyaluronan impairs vascular function and drug delivery in a mouse model of pancreatic cancer. Gut. 2013; 62(1): 112-20. PMid:22466618. http://dx.doi.org /10.1136/gutjnl-2012-302529

[34] Provenzano PP, Cuevas C, Chang AE, et al. Enzymatic targeting of the stroma ablates physical barriers to treatment of pancreatic ductal adenocarcinoma. Cancer Cell. 2012; 21(3): 418-29. PMid:22439937. http://dx.doi.org/10.1016/j.ccr.2012.01.007

[35] National Nanotechnology Initiative. [cited 2015 Nov 2]. Available from: http://nano.gov/

[36] Zamboni WC, Torchilin V, Patri AK, et al. Best practices in cancer nanotechnology: perspective from NCI nanotechnology alliance. Clin Cancer Res. 2012; 18(12): 3229-41. PMid:22669131. http://dx.doi.org/10.1158/1078-0432.CCR-11-2938

[37] Markman JL, Rekechenetskiy A, Holler E, et al. Nanomedicine therapeutic approaches to overcome cancer drug resistance. Adv
Drug Deliv Rev. 2013; 65(13-14): 1866-79. PMid:24120656. http: //dx.doi.org/10.1016/j.addr.2013.09.019

[38] Perche F, Torchilin VP. Recent trends in multifunctional liposomal nanocarriers for enhanced tumor targeting. J Drug Deliv. 2013; 2013 705265. PMid:23533772. http://dx.doi.org/10.1155/2013/ 705265

[39] Webster DM, Sundaram P, Byrne ME. Injectable nanomaterials for drug delivery: carriers, targeting moieties, and therapeutics. Eur J Pharm Biopharm. 2013; 84(1): 1-20. PMid:23313176. http: //dx.doi.org/10.1016/j.ejpb.2012.12.009

[40] Sun C, Lee JS, Zhang M. Magnetic nanoparticles in MR imaging and drug delivery. Adv Drug Deliv Rev. 2008; 60(11): 1252 65. PMid:18558452. http://dx. doi .org/10.1016/j . addr. 20 08.03 .018

[41] Yalçin S, Erkan M, Unsoy G, et al. Effect of gemcitabine and retinoic acid loaded PAMAM dendrimer-coated magnetic nanoparticles on pancreatic cancer and stellate cell lines. Biomed Pharmacother. 2014; 68(6): 737-43. PMid:25108345. http://dx.doi.org/10.1016/j .biopha.2014.07.003

[42] Danhier F, Danhier P, De Saedeleer CJ, et al. Paclitaxel-loaded micelles enhance transvascular permeability and retention of nanomedicines in tumors. Int J Pharm. 2015; 479(2): 399-407. PMid:25578367. http://dx.doi.org/10.1016/j.ijpharm.2 015.01 .009

[43] Stylianopoulos T, Economides EA, Baish JW, et al. Towards optimal design of cancer nanomedicines: multi-stage nanoparticles for the treatment of solid tumors. Ann Biomed Eng. 2015. PMid:25670323. http://dx.doi.org/10.1007/s10439-015-1276-9

[44] Patra CR, Bhattacharya R, Wang E, et al. Targeted delivery of gemcitabine to pancreatic adenocarcinoma using cetuximab as a targeting agent. Cancer Res. 2008; 68(6): 1970-8. PMid:18339879. http://dx.doi.org/10.1158/0008-5472. CAN-07-6102

[45] Li J, Di Y, Jin C, et al. Gemcitabine-loaded albumin nanospheres (GEM-ANPs) inhibit PANC-1 cells in vitro and in vivo. Nanoscale Res Lett. 2013; 8(1): 176. PMid:23594566. http://dx.doi.org /10.1186/1556-276X-8-176

[46] Jaidev LR, Krishnan UM, Sethuraman S. Gemcitabine loaded biodegradable PLGA nanospheres for in vitro pancreatic cancer therapy. Mater Sci Eng C Mater Biol Appl. 2015; 47: 407. PMid:25492170. http://dx.doi.org/10.1016/j.msec. 20 14.11 .027

[47] Makadia HK, Siegel SJ. Poly lactic-co-glycolic acid (PLGA) as biodegradable controlled drug delivery carrier. Polymers (Basel). 2011; 3(3): 1377-97. PMid:22577513. http://dx.doi.org/10. 3390/polym3031377

[48] Vaz J, Ansari D, Sasor A, et al. SPARC: A potential prognostic and therapeutic target in pancreatic cancer. Pancreas. 2015; 44(7): 1024 35. PMid:26335014. http://dx.doi.org/10.1097/MPA. 00000 00000000409

[49] Bornstein P, Sage EH. Matricellular proteins: extracellular modulators of cell function. Curr Opin Cell Biol. 2002; 14(5): 60816. PMid 12231357. http://dx.doi.org/10.1016/S0955-067 4(02) 00361-7

[50] Sato N, Fukushima N, Maehara N, et al. SPARC/osteonectin is a frequent target for aberrant methylation in pancreatic adenocarcinoma and a mediator of tumor-stromal interactions. Oncogene. 2003; 22(32): 5021-30. PMid:12902985. http://dx.doi.org/10.1038 /sj.onc. 1206807

[51] Zhivkova-Galunska M, Adwan H, Eyol E, et al. Osteopontin but not osteonectin favors the metastatic growth of pancreatic cancer cell lines. Cancer Biol Ther. 2010; 10(1): 54-64. PMid:20495387. http://dx.doi.org/10.4161/cbt.10.1.12161 
[52] Motamed K. SPARC (osteonectin/BM-40). Int J Biochem Cell Biol 1999; 31(12): 1363-6. PMid:10641790. http://dx.doi .org/10. 1016/S1357-2725 (99) 00090-4

[53] Meng H, Zhao Y, Dong J, et al. Two-wave nanotherapy to target the stroma and optimize gemcitabine delivery to a human pancreatic cancer model in mice. ACS Nano. 2013; 7(11): 10048-65. PMid:24143858. http://dx.doi .org/10.1021/nn404083m

[54] Pouyssegur J, Dayan F, Mazure NM. Hypoxia signalling in cancer and approaches to enforce tumour regression. Nature. 2006; 441(7092): 437-43. PMid:16724055. http://dx .doi .org/10.10 38/nature04871

[55] Ryan HE, Poloni M, McNulty W, et al. Hypoxia-inducible factor1alpha is a positive factor in solid tumor growth. Cancer Res. 2000; 60(15): 4010-5. PMid:10945599.

[56] Li L, Lin X, Shoemaker AR, et al. Hypoxia-inducible factor-1 inhibition in combination with temozolomide treatment exhibits robust antitumor efficacy in vivo. Clin Cancer Res. 2006; 12(15): 4747-54. PMid:16899626. http://dx.doi .org/10.1158/1078-0432.CC $\mathrm{R}-05-2842$

[57] Zhao X, Li F, Li Y, et al. Co-delivery of HIF1alpha siRNA and gemcitabine via biocompatible lipid-polymer hybrid nanoparticles for effective treatment of pancreatic cancer. Biomaterials. 2015; 46: 13-25. PMid:25678112. http://dx.doi.org/10.1016/j.bioma terials.2014.12.028

[58] de la Fuente M, Jones MC, Santander-Ortega MJ, et al. A nanoenabled cancer-specific ITCH RNAi chemotherapy booster for pancreatic cancer. Nanomedicine. 2015; 11(2): 369-77. PMid:25267700. http://dx.doi.org/10.1016/j.nano.2014.09.010

[59] Fire A, Xu S, Montgomery MK, et al. Potent and specific genetic interference by double-stranded RNA in Caenorhabditis elegans. Nature. 1998; 391(6669): 806-11. PMid:9486653. http: //dx.doi.org/10.1038/35888

[60] Hansen TM, Rossi M, Roperch JP, et al. Itch inhibition regulates chemosensitivity in vitro. Biochem Biophys Res Commun. 2007; 361(1): 33-6. PMid:17640619. http://dx.doi.org/10.1016/j .bbrc. 2007.06.104

[61] Desgrosellier JS, Cheresh DA. Integrins in cancer: biological implications and therapeutic opportunities. Nat Rev Cancer. 2010; 10(1): 9-22. PMid:20029421. http://dx.doi.org/10.1038/nrc2748

[62] Davis PJ, Davis FB, Mousa SA, et al. Membrane receptor for thyroid hormone: physiologic and pharmacologic implications. Annu Rev Pharmacol Toxicol. 2011; 51: 99-115. PMid:20868274. http://dx .doi.org/10.1146/annurev-pharmtox-010510-100512

[63] Davis PJ, Glinsky GV, Lin HY, et al. Cancer cell gene expression modulated from plasma membrane integrin alphavbeta3 by thyroid hormone and nanoparticulate tetrac. Front Endocrinol (Lausanne). 2014; 5: 240. PMid:25628605. http://dx.doi.org/10.3389/f endo. 2014.00240

[64] Davis PJ, Glinsky GV, Lin HY, et al. Corrigendum: "Cancer cell gene expression modulated from plasma membrane integrin alphavbeta3 by thyroid hormone and nanoparticulate tetrac". Front Endocrinol (Lausanne). 2015; 6: 98. PMid:26106368. http://dx.doi.org/1 $0.3389 /$ fendo .2015 .00098

[65] Bharali DJ, Yalcin M, Davis PJ, et al. Tetraiodothyroacetic acidconjugated PLGA nanoparticles: a nanomedicine approach to treat drug-resistant breast cancer. Nanomedicine (Lond). 2013; 8(12): 1943-54. PMid:23448245. http://dx.doi.org/10.2217/nnm.1 2.200

[66] Yalcin M, Lin HY, Sudha T, et al. Response of human pancreatic cancer cell xenografts to tetraiodothyroacetic acid nanoparticles. Horm Cancer. 2013; 4(3): 176-85. PMid:23456390. http: //dx.doi.org/10.1007/s12672-013-0137-y
[67] McCarroll JA, Phillips PA, Santucci N, et al. Vitamin A inhibits pancreatic stellate cell activation: implications for treatment of pancreatic fibrosis. Gut. 2006; 55(1): 79-89. PMid:16043492. http: //dx.doi.org/10.1136/gut.2005.064543

[68] Froeling FE, Feig C, Chelala C, et al. Retinoic acid-induced pancreatic stellate cell quiescence reduces paracrine Wnt-beta-catenin signaling to slow tumor progression. Gastroenterology. 2011; 141(4): 1486-97, 97 e1-14. PMid: 2170458. http://dx.doi .org/10.10 $53 / j$.gastro.2011.06.047

[69] Michael A, Hill M, Maraveyas A, et al. 13-cis-Retinoic acid in combination with gemcitabine in the treatment of locally advanced and metastatic pancreatic cancer-report of a pilot phase II study. Clin Oncol (R Coll Radiol). 2007; 19(2): 150-3. PMid:17355112. http://dx.doi.org/10.1016/j.clon.2006.11.008

[70] Tanemura M, Miyoshi E, Nagano H, et al. Cancer immunotherapy for pancreatic cancer utilizing alpha-gal epitope/natural anti-Gal antibody reaction. World J Gastroenterol. 2015; 21(40): 11396410. PMid:26523105. http://dx.doi.org/10.3748/wjg.v21 . i40.11396

[71] Uram JN, Le DT. Current advances in immunotherapy for pancreatic cancer. Curr Probl Cancer. 2013; 37(5): 273-9. PMid:24331182. http://dx.doi.org/10.1016/j.currprobl cancer.2013.10.004

[72] Salman B, Zhou D, Jaffee EM, et al. Vaccine therapy for pancreatic cancer. Oncoimmunology. 2013; 2(12): e26662. PMid:24498551. http://dx.doi.org/10.4161/onci. 26662

[73] Zheng L. Does vaccine-primed pancreatic cancer offer better candidates for immune-based therapies? Immunotherapy. 2014; 6(10): 1017-20. PMid:25428641. http://dx.doi.org/10.2217/imt.1 4.87

[74] Paniccia A, Merkow J, Edil BH, et al. Immunotherapy for pancreatic ductal adenocarcinoma: an overview of clinical trials. Chin J Cancer Res. 2015; 27(4): 376-91. PMid:26361407. http://dx.doi.org /10.3978/j.issn.1000-9604.2015.05.01

[75] Kleponis J, Skelton R, Zheng L. Fueling the engine and releasing the break: combinational therapy of cancer vaccines and immune checkpoint inhibitors. Cancer Biol Med. 2015; 12(3): 2018. PMid:26487965. http://dx.doi.org/10.7497/j.issn. 20 95-3941.2015.0046

[76] Chin YT, Lai HY, Tang HY, et al. Anti-PD-L1 activity of Nanodiamino-tetrac (Nanotetrac) in cancer cells. Poster presented at: AACR Research Frontiers in Basic Cancer Science Conference; 2015 Oct 13 -15; Philadelphia, PA.

[77] Bhargava A, Mishra D, Banerjee S, et al. Dendritic cell engineering for tumor immunotherapy: from biology to clinical translation. Immunotherapy. 2012; 4(7): 703-18. PMid:22853757. http: //dx.doi.org/10.2217/imt.12.40

[78] Steinman RM, Banchereau J. Taking dendritic cells into medicine. Nature. 2007; 449(7161): 419-26. PMid:17898760. http://dx.d oi.org/10.1038/nature06175

[79] Koido S, Homma S, Okamoto M, et al. Treatment with chemotherapy and dendritic cells pulsed with multiple Wilms' tumor 1 (WT1) specific MHC class I/II-restricted epitopes for pancreatic cancer. Clin Cancer Res. 2014; 20(16): 4228-39. PMid:25056373. http: //dx.doi.org/10.1158/1078-0432.CCR-14-0314

[80] Koido S, Homma S, Takahara A, et al. Current immunotherapeutic approaches in pancreatic cancer. Clin Dev Immunol. 2011; 2011: 267539. PMid:21922022. http://dx.doi.org/10.1155/2011/ 267539

[81] Bapsy PP, Sharan B, Kumar C, et al. Open-label, multi-center, nonrandomized, single-arm study to evaluate the safety and efficacy of dendritic cell immunotherapy in patients with refractory solid 
malignancies, on supportive care. Cytotherapy. 2014; 16(2): 23444. PMid:24438902. http://dx.doi.org/10.1016/j.jcyt. 20 13.11 .013

[82] Takakura K, Koido S, Kan S, et al. Prognostic markers for patient outcome following vaccination with multiple MHC Class I/II-restricted WT1 peptide-pulsed dendritic cells plus chemotherapy for pancreatic cancer. Anticancer Res. 2015; 35(1): 555-62. PMid:25550602.

[83] Yin T, Shi P, Gou S, et al. Dendritic cells loaded with pancreatic Cancer Stem Cells (CSCs) lysates induce antitumor immune killing effect in vitro. PLoS One. 2014; 9(12): e114581. PMid:25521461. http://dx.doi.org/10.1371/journal.pone.0114581

[84] Rong Y, Qin X, Jin D, et al. A phase I pilot trial of MUC1peptide-pulsed dendritic cells in the treatment of advanced pancreatic cancer. Clin Exp Med. 2012; 12(3): 173-80. PMid:21932124. http://dx.doi.org/10.1007/s10238-011-0159-0

[85] Oji Y, Nakamori S, Fujikawa M, et al. Overexpression of the Wilms' tumor gene WT1 in pancreatic ductal adenocarcinoma. Cancer Sci. 2004; 95(7):583-7. PMid:15245594. http://dx.doi.org/10.11 11/j.1349-7006.2004.tb02490.x

[86] Aarntzen EH, Figdor CG, Adema GJ, et al. Dendritic cell vaccination and immune monitoring. Cancer Immunol Immunother. 2008; 57(10): 1559-68. PMid:18618110. http://dx.doi.org/10.1007/s0026 2-008-0553-y

[87] Romani N, Gruner S, Brang D, et al. Proliferating dendritic cell progenitors in human blood. J Exp Med. 1994; 180(1): 83-93. PMid:8006603. http://dx.doi.org/10.1084/jem.180.1.83

[88] Shindo Y, Hazama S, Maeda Y, et al. Adoptive immunotherapy with MUC1-mRNA transfected dendritic cells and cytotoxic lymphocytes plus gemcitabine for unresectable pancreatic cancer. J Transl Med. 2014; 12: 175. PMid:24947606. http://dx.doi.org/10.1186 /1479-5876-12-175

[89] Masaki Y, Oka M, Ogura Y, et al. Sialylated MUC1 mucin expression in normal pancreas, benign pancreatic lesions, and pancreatic ductal adenocarcinoma. Hepatogastroenterology. 1999; 46(28): 2240-5. PMid:10521973.

[90] Foster JH, Lundy J. Liver Metastases. Curr Probl Surg. 1981; 18(3): 157-202. PMid:7016459. http://dx.doi.org/10.1016/S0011 -3840 (81) 80009-3

[91] Li C, Heidt DG, Dalerba P, et al. Identification of pancreatic cancer stem cells. Cancer Res. 2007; 67(3): 1030-7. PMid:17283135. http://dx.doi.org/10.1158/0008-5472.CAN-06-2030

[92] Yin T, Wei H, Gou S, et al. Cancer stem-like cells enriched in Panc-1 spheres possess increased migration ability and resistance to gemcitabine. Int J Mol Sci. 2011; 12(3): 1595-604. PMid:21673909. http://dx.doi.org/10.3390/ijms12031595

[93] Moore MJ, Goldstein D, Hamm J, et al. Erlotinib plus gemcitabine compared with gemcitabine alone in patients with advanced pancreatic cancer: a phase III trial of the National Cancer Institute of Canada Clinical Trials Group. J Clin Oncol. 2007; 25(15): 1960-6. PMid:17452677. http://dx.doi.org/10.1200/JC0.2 006.07 .9525

[94] Cunningham D, Chau I, Stocken DD, et al. Phase III randomized comparison of gemcitabine versus gemcitabine plus capecitabine in patients with advanced pancreatic cancer. J Clin Oncol. 2009; 27(33):
5513-8. PMid:19858379. http://dx.doi.org/10.1200/JC0.2 009.24 .2446

[95] Philip PA, Benedetti J, Corless CL, et al. Phase III study comparing gemcitabine plus cetuximab versus gemcitabine in patients with advanced pancreatic adenocarcinoma: Southwest Oncology Groupdirected intergroup trial S0205. J Clin Oncol. 2010; 28(22): 360510. PMid:20606093. http://dx.doi.org/10.1200/JC0. 2009. 25.7550

[96] Van Cutsem E, Vervenne WL, Bennouna J, et al. Phase III trial of bevacizumab in combination with gemcitabine and erlotinib in patients with metastatic pancreatic cancer. J Clin Oncol. 2009; 27(13): 2231-7. PMid:19307500. http://dx.doi.org/10.1200/JCO.2 008.20 .0238

[97] Colucci G, Labianca R, Di Costanzo F, et al. Randomized phase III trial of gemcitabine plus cisplatin compared with single-agent gemcitabine as first-line treatment of patients with advanced pancreatic cancer: the GIP-1 study. J Clin Oncol. 2010; 28(10): 164551. PMid:20194854. http://dx.doi.org/10.1200/JC0. 2009. 25.4433

[98] Bernhardt SL, Gjertsen MK, Trachsel S, et al. Telomerase peptide vaccination of patients with non-resectable pancreatic cancer: A dose escalating phase I/II study. Br J Cancer. 2006; 95(11): 1474 82. PMid:17060934. http://dx.doi.org/10.1038/sj.bjc. 66 03437

[99] Hardacre JM, Mulcahy M, Small W, et al. Addition of algenpantucel$\mathrm{L}$ immunotherapy to standard adjuvant therapy for pancreatic cancer: a phase 2 study. J Gastrointest Surg. 2013; 17(1): 94-100; discussion p100-1.

[100] Lutz E, Yeo CJ, Lillemoe KD, et al. A lethally irradiated allogeneic granulocyte-macrophage colony stimulating factor-secreting tumor vaccine for pancreatic adenocarcinoma. A Phase II trial of safety, efficacy, and immune activation. Ann Surg. 2011; 253(2): 328 35. PMid:21217520. http://dx.doi.org/10.1097/SLA.0b013 e3181fd271c

[101] Le DT, Brockstedt DG, Nir-Paz R, et al. A live-attenuated Listeria vaccine (ANZ-100) and a live-attenuated Listeria vaccine expressing mesothelin (CRS-207) for advanced cancers: phase I studies of safety and immune induction. Clin Cancer Res. 2012; 18(3): 858-68. PMid:22147941. http://dx.doi.org/10.1158/1078-0432.CC $\mathrm{R}-11-2121$

[102] Selby MJ, Engelhardt JJ, Quigley M, et al. Anti-CTLA-4 antibodies of $\operatorname{IgG} 2 \mathrm{a}$ isotype enhance antitumor activity through reduction of intratumoral regulatory T cells. Cancer Immunol Res. 2013; 1(1): 32-42. PMid:24777248. http://dx.doi.org/10.1158/2326-6 066. CIR-13-0013

[103] Freeman GJ, Long AJ, Iwai Y, et al. Engagement of the PD-1 immunoinhibitory receptor by a novel B7 family member leads to negative regulation of lymphocyte activation. J Exp Med. 2000; 192(7): 1027-34. PMid:11015443. http://dx.doi.org/10.1084/jem.1 92.7 .1027

[104] Brahmer JR, Tykodi SS, Chow LQ, et al. Safety and activity of antiPD-L1 antibody in patients with advanced cancer. N Engl J Med. 2012; 366(26): 2455-65. PMid:22658128. http://dx. doi.org/1 $0.1056 /$ NEJMoa1200694 